\title{
Editor's Introduction: The Office of Information and Regulatory Affairs - Past, Present and Future
}

It is with great pride and delight that we present the following collection of seven papers addressing the role of the Office of Information and Regulatory Affairs (OIRA) historically and in the future. It is an intellectually productive exercise for the beginning of a Presidential election year in the United States where benefits and costs of regulation are a campaign issue.

The intellectual exchange to follow begins with a long paper by James Tozzi, who is well known as a chronicler of the activities of OIRA. We are indeed fortunate to have Jim's paper to be the vehicle to generate discussion of regulatory activities of the federal executive branch of government in the U.S. Additionally exciting is that we have been able to present commentary by six former heads of OIRA on the Tozzi paper and their views of the past, present and future of the agency. The group consists of both Democratic and Republican appointees, including the first Administrator of the agency. In their historical order of service, we have comments by Jim Miller, Chris DeMuth, Sally Katzen, John Graham, Susan Dudley, and Howard Shelanski. We are grateful for the insights of all the seven authors.

Finally, I wish to acknowledge my recently deceased colleague, Michael Uhlmann, who had the idea for this project. Michael was an exceptional intellect, a lawyer with a $\mathrm{PhD}$ in political science, who was both an Assistant Attorney General and a Special Assistant to the President. He was there at the beginning of both Council on Wage and Price Stability (CWPS) and OIRA. Michael is the only person I know who has a Razor named after him that relates to regulatory affairs. ${ }^{1}$ I only wish he were alive to enjoy the following seven papers as much as the rest of us. Bon Appetit'.

Thomas J. Kniesner

Editor, Journal of Benefit-Cost Analysis

1 As Casey Stengel once remarked, "You can look it up." 